\title{
NOTES ON THE MALE GENITAL SYSTEM IN CERTAIN LEPIDOPTERA.*
}

By Herbert Ruckes, A. M.

\section{INTRODUCTION.}

Changes going on in organisms, whether studied grossly or minutely, have always been interesting subjects and many times astonishing truths have been revealed, where they were least expected to occur.

A great deal of the work carried on in entomological histology, especially under the heading of metamorphosis, has been relative to the muscular system, alimentary tract, adipose tissue, etc., while little attention has been given to other equally important systems. This is true of the reproductive system; so for this reason a study of the morphological and histological metamorphosis of the male genital tract in certain Lepidoptera was attempted.

The study was worked out under the direction of Professor W. A. Riley, to whom the writer is indebted for his prolonged patience and valuable criticism, and for the use of prepared slides. The writer also wishes to thank Professor Lester W. Sharp for his advices regarding the subject of spermatogenesis and for the use of his slides of maturation mitosis in insects. To Mr. John R. Eyer thanks are also due for use of his valuable slides of the genitalia of a large number of Lepidoptera.

The Lepidoptera were chosen to be worked on, for the metamorphosis could be readily controlled, by artificial means; and besides, this group shows apparently a greater diversity in the form of the genital system than most other orders. The Saturniidæ were chosen because when the study was first begun, they were most abundant.

Studies in the morphology and internal anatomy of insects date back to the earliest zoologists. Dissection of forms, however, did not properly commence till the advent of the microscope, so that we find the first worker on the genital system to be Malpighi (1669) whose treatise on the internal

* Contribution from the Entomological Laboratory of Cornell University. This paper is part of a thesis (by title, On the Metamorphosis of the Genital System in the Saturniidae) presented as part requirement for the degree of Master of Arts. 
structure of Bombyx mori Linn. is now a classic. From that date onward we find little concerning the genital system till, in 1815, Herold produced his paper on the metamorphosis of Pieris brassica Linn., including other systems besides the reproductive. This paper formed the basis for subsequent work on the genital tract for it discussed the peculiar migration of the testes to a median plane and, there, complete fusion into a spherical body. It has been proved that this condition is by no means typical of all Lepidoptera, being representative of only the higher Rhophalocera. From the time of Herold's work till 1865 seems to be a more or less stagnant period for work of this sort. In 1865 Bessels published a few observations. From the morphological point of view the greatest contributions have been given by Chlodkovsky (1880-1913). Though short, these papers are thorough and explicit, explaining the evolution of the Lepidopterous genital tracts and their genealogical relationship to those of other orders. Since 1884, histological and cytological methods, combined with a continued increase of our knowledge of chromosomes and chromosome reduction, have led to the production of a vast amount of work and a large number of observations on all groups of insects. A great deal of this work has been restricted to the study of the maturation of sex cells, regardless of the structure and function of the surrounding tissues. Those doing the most comprehensive general studies since 1884 are LaValette St. George, Verson, Blatter, Berlese, Toyama and at a recent date (1913) Zick. The views and criticisms of these authors will be discussed as their particular points come up.

\section{METHODS AND MATERIAL.}

As above stated the Saturniidæ furnished the basis of the following study, though they were by no means the only forms observed. The following is a list of species that were used:

LEPIDOPTERA.

Philosamia cynthia Drury.

Samia cecropia Linn.

Callosamia promethia Drury.

Thelea polyphemus Cramer.

Pieris (Pontia) rapa Linn.

Anosia plexippus Linn.

Vanessa antiopa Linn.
ORTHOPTERA.

Dissoteira carolina Linn.

HEMIPTERA.

Anasa tristis DeGeer.

Euschistus fissilis Uhler.

E. variolarius Stal.

Nezara viridula Stal. 
By far the greatest part of the work was done on $P$. cynthia, since it was most readily available. S. cecropia offered the best material to follow out morphological changes - being the largest form. Material was procured at Ithaca and New York City.

For various ends, various technique was used. The material for spermatogenesis was killed and fixed in Benda's fluid, Zenkers, Gilson's or Herman's mixtures. Pereyni's reagent was found to be very good for synaptic stages of mitosis. A new mixture, formulated as follows, fixed "ring" stages better than any of the more common solutions:

$2 \%$ copper sulphate........... 3 parts

$2 \%$ platinum chlorid ........... 2 parts

Acetic acid ................ 6-10 drops to every 100 c. c.

Water (distilled)............... 10 parts

This solution is strictly a nuclear fixer. For the study of the tissues other than the germ cells, Gilson's or Herman's mixtures were employed.

Of the stains, Weigert's copper haemotoxylin was found best, this staining cytoplasm with as much exactness as the nucleoplasm. Mallory's connective tissue stain was indispensable for the muscular and fibrous coats of the various organs, especially the coats of the testis. Delafield's haemotoxylin counterstained with picro-fuchsin was found to be very good for determining the presence of a cuticula covering.

In making dissections, especially during the larval and early pupal periods, when the organs of the genital system are very delicate and very difficult to see, the preparations were lightly stained with Delafield's haemotoxylin, the stain being dropped on the dissection after the water had been poured out of the pan. In preparations made in this way, the finer organs like the vasa deferentia, ligaments, and nerves, could be followed along their course. These structures stain deeply, while the fat lobules do not.

In order to make a more detailed study of the nerves investing the caudal portion of the abdomen, specimens were injected with $1 \%$ Grübler's "B-X" methylene blue in a .9\% salt solution and allowed to remain so treated, in a living condition for from twelve to twenty-four hours. The earlier stages were found to take up the stain more readily than the adults. In adults thirty-six hours were required to have this intra vitam method take effect. 


\section{PARTS OF THE ADULT MALE GENITAL SYSTEM.}

In insects the male reproductive system consists of a pair of testes, a vas deferens, leading from each testis into a set of ducts that vary greatly in different groups of insects (Cf. Berlese Gli Insetti, Figure 1087), and a penis. The testes themselves are composed of testicular tubes. These tubes may be numerous or few; in the Lepidoptera there are four; the tubes also may be separated (Hepialus, Fig. 1A) or they may be fused (Philosamia, Fig. 1 B and E, Fig. 2), and in some cases the two testes may approach the median plane and fuse Pieris, Fig. 1 D). In all cases the testicular tubes are homologues of the ovarian tubes. In the Saturniidæ the testes lie in a latero-dorsal position, close to the alimentary canal, just under the fifth and sixth segments of the abdomen. They are reniform in shape, the convex side of each, called the apical region, being mesad; the concave region known as the hilum lies ectad, and is the junction of the vas deferens and the four testicular tubes (Fig. 3). The vasa deferentia are long irregular tubes, extending caudad to the eighth segment, where each passes through the loop-hole of the tenth abdominal nerve (Fig. 4, Vd). After passing through the nerve each turns cephalad to the seventh segment where it unites with the seminal vesicle. The seminal vesicles we may consider as distended portions of the vasa deferentia, each joined anteriorly to a long convoluted tube known as the accessory gland; posteriorly they unite to form the upper end of the ejaculatory duct: The ejaculatory duct is really in two parts; the upper end which in early pupal stages may readily be seen to consist of two approximated short tubes (prolongations of the seminal vesicles) is known in the adult as the ductus ejaculatorius duplex; the posterior and longer portion, which is an invagination of the ectoderm (it bears a cuticula or chitinous lining), is known as the ductus ejaculatorius simplex, and terminates in a very muscular "bulb," the bulbus ejaculatorius at the base of the penis. This last named organ is the caudal extremity of the entire genital system. It is wholly chitinous, bearing various types of prolongations, and is connected with the body wall by means of muscles. It is capable of extrusion during copulation. (The adult system is figured in Fig. 1E). 
Of the parts of the reproductive system, the germ cells, the ductus ejaculatorius simplex, and the penis are formed from the ectoderm. The remaining organs, and the muscular covering of the ductus ejaculatorius simplex are derived from the mesoderm.

\begin{tabular}{|c|c|}
\hline ECtODERM & Mesoderm \\
\hline $\begin{array}{l}\text { Germ cells } \\
\text { (Verson's Cell)? } \\
\text { Epithelium of ejaculatory duct simplex } \\
\text { Penis }\end{array}$ & $\begin{array}{l}\text { Testicular coats } \\
\text { (Verson's Cell, or Follicula repithelium)? } \\
\text { Accessory glands } \\
\text { Vasa deferentia } \\
\text { "Ejaculatory duct duplex", } \\
\text { Muscles of all the above. } \\
\text { Muscles of the ejaculatory duct simplex }\end{array}$ \\
\hline
\end{tabular}

The origin of the various organs, and their constituent tissues has been a problem of great importance in insect embryology. It is not the purpose of this paper to deal with the various views set forth by embryologists, but to confine the remarks to post-embryonic development.

\section{THE NERVES.}

The nerves innervating the reproductive organs are complicated and deserve special mention. Their development and changes occurring in them during the pupal and adult periods are subjects that well deserve detailed study. Some interesting features are as follows.

In the early pupal stage (Fig. 4), the seventh abdominal ganglion is closely approximated to the eighth plus tenth ganglia, near the caudal portion of the seventh abdominal sternite. Three pairs of nerves arise from the seventh ganglion; these are the seventh anterior, going to the seventh spiracles, the seventh posterior going to the body tissue, and the seventh splanchnic or sympathetic, also innervating the seventh spiracles. The posterior nerve is somewhat reduced (vestigial); this is frequently the case in Lepidoptera.

The caudal ganglion, which apparently is a fusion or condensation of the eighth, ninth and tenth ganglia, gives rise to three or four pairs of nerves. The most cephalic of these is the eighth sympathetic, which innervates the vestigial eighth spiracle. The next nerve has two branches, a long heavy one (undoubtedly the eighth anterior) passes to the eighth spiracle, 
while the shorter and weaker branch (the eighth posterior) extends into the body tissue. In Samia cecropia, the ninth nerve arises separately from the ganglion. In Philosamia cynthia, it is joined for a distance with the tenth nerve. In either case, this nerve has two branches, a long anterior branch, which extends caudad to the juncture of the seminal vesicles, and the vasa deferentia, innervating this juncture, and forming a prominent plexus there. This may be called the vesicular plexus (Vp. Fig. 4). The shorter branch is homologous with the shorter branches of the seventh and eighth nerves and is no doubt the ninth posterior. The tenth nerve is very heavy and long. It is the most interesting of all; the strong anterior branch extends caudad, to the region of the vesicular plexus, where it forms a prominent loop hole, through which the vas deferens passes; this nerve continues and gives rise to delicate branches that form what may be called the caudal plexus (Cp. Fig. 4), innervating the tissue that later becomes part of the genital appendages. From each loop hole a delicate branch extends entad, and unites with the vesicular plexus. The tenth posterior nerve passes caudad, and supplies the same tissue that the caudal plexus innervates.

What changes take place during the transformation stages have not been studied. The caudal plexus no doubt forms the nerve supply for the genitalia, and the vesicular plexus probably controls the muscles of the ducts.

\section{HISTOLOGY OF THE TESTIS.}

As previously stated, each testis consists of four chambers, or testicular tubes, combined, and surrounded by a capsule. Regardless of the form of a testis, from the histological aspect, one may consider it as consisting of two main parts, an ectodermal part of the sex cells themselves, and a mesodermal portion comprising the follicular epithelium and the various coats that make up the wall of the testis. A study of the sex cells involves observations on their origin, growth, maturation and transformation, topics that come under the heading of spermatogenesis and which are not to be treated in this paper. (Cf. Pauline Dederer, Biol. Bull., Vol. 13-Spermatogenesis in P. cynthia). The author wishes to deal solely with the mesodermal tissue. This may readily be considered under two headings, 
the follicular epithelium and the testicular envelopes. It is simpler to treat, first, the envelopes, and then consider the epithelium, since the latter needs some explanation.

In studying the testicular chambers, one finds that their lining consists of a thin structureless membrane, which is the basement membrane (Bm.-Figs. 5, 6, 7), of the follicular epithelium; the distribution and function of the follicular epithelium will be explained later. Outside of the basement membrane is a prominent wall, which in the Lepidoptera, in general, consists of two heavy layers, an inner testicular tube coat (Ttc.-Fig. 5, 6, 7) and an outer capsular coat (Cc.-Fig. $5,6,7)$. Besides these on the periphery of the capsular coat is a thin layer of material that is apparently chitinous in nature and is probably due to the degeneration of tracheæ, which are very abundant on the testis and ramify freely over its surface.

The Testicular Tube Coat (Figs. 5, 6, 7). Of the two layers forming the wall of the testis, the inner one, or testicular tube coat, is the more interesting. The coat not only surrounds the entire testis but sends three partitions or septæ toward the hilum, forming the four chambers or testicular tubes. The cells composing this layer are very peculiar. They are of mesodermal origin, and assume the appearance of true connective tissue. They render the coat loose in its texture and fibrous in its nature. In most cases (in Lepidoptera) the cells are separated from one another, leaving large intercellular spaces in which delicate cyloplasmic fibres, from the periphery of the cells, ramify and anastomose. These two features give the coat its loose and fibrous appearance. The shape of the cells varies according to the species of insect studied. In P. cynthia, they are elongated and spindle shaped, in $C$. promethia, they are angular, less elongated, closer and have fewer cytoplasmic prolongations. The cytoplasm in all cases is drawn out and fibrous in nature. What is more interesting than the position of the cells as to shape and texture, is their content. They are apparently storage tissues, either for reserve materials or for products of katabolism. In the case of the Saturniids they have a prominent fat content (Fd.-Fig. 5, 6). The fat globules show very plainly and beautifully in osmic acid preparations. When stained with Mallory's C. T. stain, they stand out as brilliant orange or orange-red droplets in the pinkish cytoplasm. In Pieris, Lycaena, and species in which 
the testes are colored, this coat is the repository for the pigment granules (Pg.-Fig. 7), which are believed to be waste products of urate character. Fine purplish and brown granules can be readily observes in small bits of this coat torn from the testis of Pieris larva and viewed in toto.

-Through the interstices of this tissue, tracheæ having passed through the capsular coat, branch and ramify. These tracheæ also pass through the basement membrane into the chambers of the testis, there to resolve themselves into tracheoles which lie in close relationship with the groups of spermatocysts. This condition is to be expected since the sex cells are rapidly growing bodies, and consequently need relatively large amounts of oxygen for metabolism. Choldkovsky (1880), stated that the tracheæ never penetrate the basement membrane, and enter the follicular chambers. Koschevnikoff (1891) disproved this statement for Apis mellifica, and the present writer has found that each testicular chamber has small masses of tracheoles in it, which can be traced back to the tracheæ passing through the basement membrane, usually the membrane lying approximate to the septæ.

The Capsular Coat. Less interesting than the testicular tube coat is the capsular coat, surrounding the entire testis, and in some cases easily separated from its inner neighbor. Usually about the same in thickness as the inner coat, this outer layer of cells shows a marked contrast, in view of the nature of the cytoplasm and the compactness of the tissue. The layer stains poorly, but on close examination, it may be seen that the cytoplasm is very spongy and granular. The cells are usually cuboidal, and very closely placed. They may be only one layer of cells, as in C. promethia and Pieris rapae. The nuclei are usually spherical and centrally placed. There is no pigment or fat distributed in the outer coat.

As mentioned above, over the periphery of the capsular coat lies a layer of structureless material that has all evidence of being chitin or of chitinous origin. It is flakey, tough and readily stains with iron haemotoxylin, picro-fuchsin, and aniline blue. It originates probably through the degeneration of the tracheæ which are abundant over the surface of the testis. In breaking down, the chitin composing the tenidia becomes chemically changed, assumes a plastic consistency, and flows 
together to make a homogeneous cover over the entire reproductive gland. This layer may readily be called the tracheal membrane (Tm., Figs. 5, 6, 7).

The Follicular Epithelium. So much for the coats of the testis. Each of the four tubes in each testis, is the male homologue of each ovarian tube. Therefore there must be a follicular epithelium. Previously it was stated that the lining of each chamber consisted of a delicate basement membrane. The basement membrane in all epithelia is on the ental periphery of the cells. Hence, the follicular epithelium must be somewhere inside of the follicular chamber. Where is it and what is its nature? That is the question that has puzzled a great number of workers on this subject.

Verson (1889) described a peculiar cell occurring in the apical region of each testicular chamber of certain insects. Other authors (La Valette St. George, Spichardt, Tischomiroff) have studied this cell (called Verson's cell, Spichardt's cell, la cellule geante, the apical cell, etc.), and have given various interpretations as to its structure and function.

Balbiani (1866) is probably the first to have noticed this peculiar structure; he considered it a mother cell for the spermatogonia. Spichardt (1886) regarded the element in question as the primordal germ cell, forming nuclei at its periphery.

Verson, in studying Bombyx mori, explained that this peculiar gigantic cell, produced protoplasmic extensions, fibrous in nature, that formed a complete meshwork throughout the testicular chamber. In the meshes of this net, the spermatogonia are at first scattered, then they become collected, and finally a spermatocyst or a group of germ cells surrounded by a capsule, is formed.

Verson believed, however, that the giant cell was a primordal spermatogonium. Cholodkovsky (1894) upheld the view of Verson.

Toyama (1894), in studying Bombyx mori, believed that there occurred, in the apical portion of each chamber, an invagination of the testicular wall, carrying with it an enlarged and specialized cell, which later lost its connection with the coat of the testis. This became the stellate cell, described by Verson. It had no genetic relationship with the spermatogonia. 
LaValette St. George (1897) believed that Verson's cell was simply a transformed spermatogonium (hence, a sister and not a mother-cell to primary germ cells), giving forth prolongations that became the spermatocyst capsules.

Tichomiroff (1898) probably added the most to the studies of the apical cell. He definitely proved it to give rise to the capsules of the spermatocysts; it had no genetic relationship with the sex cells, it gave off nuclei to the capsules, and was in nature connective tissue.

Truly, to try to understand the significance of Verson's cells, from simply a study of the testes of the Lepidoptera, would be very difficult and confusing. By making comparisons with the structures of the testes of other insects, the true homology of the apical cell may be understood.

In most insects there is a thin, delicate layer of cells lining the testicular chamber, this layer, it has definitely been shown, gives rise to the spermatocyst capsule, by sending into the interior of the chambers, delicate protoplasmic prolongations that envelop groups of spermatogonia. This layer, frequently called the cystogenous tissue, is nothing more or less than the follicular epithelium of the testis, and comparable in all respects with the follicular epithelium of the ovarian tubes. In the Lepidoptera the state of affairs is so modified as to present an apparent absence of follicular spithelium. Comparative anatomy shows, however, that the capsular tissue in one case arises from a definite epithelium, while in the other it arises from a single enlarged apical cell. Homologizing, then, Verson's cell (Fig. 7), must be a localization and reduction of the follicular epithelium, playing the same role, i. e., that of nutrition, as does the epithelium in the ovary. Due to this special disposition of the epithelium it has lost its characteristic form and assumed a condition somewhat fibrous and similar to connective tissue.

Most investigators have missed the significance of Verson's cell, because they did not study it in stages early enough. It no doubt arises from the mesoderm, as does the follicular epithelium in the female, and only during embryonic development can its disposition be thoroughly understood.

In the larval stages, after all the spermatogonia have been gathered into spermatocysts, the apical cell disintegrates, for it is no longer needed. The capsule of each spermatocyst can readily offer all the nutriment that is needed by the growing germ cells (Fig. 8). 
The Histology of the Genital Tubes.

\section{A. VAS DEFERENS.}

From each testis the vas deferens extends caudad to the seminal vesicles. In larval and early pupal stages these efferent ducts are straightish, delicate, almost invisible tubes. They look like very fine transluscent threads leading to the little papilla in the eighth segment, that later becomes the remaining portion of the genital tract. During the larval and early pupal stages, the vas deferens is uniform in diameter and possesses a prominent lumen, which is regular (i. e., without ridges) in its contour. During these stages the cellular structure is represented by Figure 9. The cells are short cylindrical or columnar, possess a rather uniformly staining cytoplasm, and show a prominent central nucleus. The chromatin of these cells occurs in irregular masses, staining prominently. These masses are rather large. The outer covering of the efferent duct may be seen as a fibrous coat that later becomes a layer of circular muscle.

As the vas deferens grows in length, it becomes convoluted; coincident with its growth in length, there is a corresponding increase in diameter. Cell division takes place very rapidly, during the mid-pupal period. In Figures 10, 11 and 12 we have represented the changes that occur during this time. At first the cells simply grow in length (Fig. 8), becoming tallcolumnar; the nuclei are still very prominent and the chromatin remains in irregular masses. The cytoplasm begins to become somewhat less dense near the tip of the cells, and begins to show a vacuolated appearance. At first it was thought that this condition was an artifact due to improper fixation. Its constancy led to the abandonment of the idea. The outer coat becomes heavier.

A little later stage will show the conditions represented in Figure 11. Marked changes are beginning. Some of the cells remain stunted or are suppressed in their development. Their neighbors continue to elongate and we have at first a slight irregularity in the contour of the lumen. Parallel with this change, the cytoplasm becomes definitely vacuolate at the tips of the cells, and a change takes place in the nucleus. The chromatin begins to break up into smaller particles and these 
have a tendency to round off. Whether this change has anything to do with the secretory activity of the cells the author is not prepared to say. The activity of the nucleolus was not studied. At any rate, there is a very evident change in the character of the chromatin.

Continuing a step further, we get a condition represented by Figure 12. The rapidly elongating cells crowd over one another, and we have the formation of a little nest-like mass of cells. The function of the nidus in the epithelium of the digestive tract is to replace cells, as they are cast off into the lumen. As far as was determined in the vas deferens, there is no migration of the cells into the lumen, and therefore these groups of cells should be called pseudonidi. The vacuolization continues, and the chromatin now appears as large granules. The nuclei remain round or oval and centrally placed.

There is a gradual, but very prominent growth of the cells in the vas deferens from now on till we reach the end of the pupal period when several changes take place rather rapidly. The pseudonidi become very prominent, and the contour of the lumen becomes markedly rigid, as figured in Fig. 16. The muscle layer has been formed and outside of it is the peritoneal membrane. The most striking feature of this stage is the structure of the epithelial cells (Fig. 12). They have become totally vacuolate, and throughout the cytoplasm occur prominent, deep staining particles that are evidently secretion droplets; where these particles come from has not been determined. The nuclei migrate to the periphery of the cell and become quite large, but the chromatin appears in very fine granules, producing a condition that does not differentiate the nucelus very well from the rest of the cell. The nuclei assume the shape of the cell. Between the muscle layer and the cells is a prominent basement membrane.

The condition of the cells at the time of the emergence of the imago may be represented by Fig. 14. The number of secretion granules is reduced, but we have in the lumen of the duct, a whitish liquid containing also an abundance of sperms. This is the seminal fluid and has been produced by the cells of vas deferens. The lower portions of the cells show a peculiar fibrous condition of the cytoplasm. This is very difficult to illustrate. The tips still show prominent vacuoles. 
After copulation, all the secretion droplets have passed from the cytoplasm and this becomess still more fibrous in its nature. The vacuoles persist at the tips. (Fig. 15).

The above described metamorphosis takes place in the upper two-fifths of the efferent duct. The lower two-fifths is somewhat similar, though the lumen remains somewhat larger, and the pseudonidi are more prominent. The middle fifth of the tube remains as it was in its larval, or early pupal condition, that of a thin, uniform duct, with cells cuboidal and without pseudonidi. Secretion takes place in the upper portion and in the lower portion of the vas deferens, but not in the middle part.

\section{B. THE SEMINAL VESICLES.}

These organs may be considered as simply distensions of the vasa deferentia; their epithelia have the same growth tendency, i. e., to form pseudonidi. However, the development of the pseudonidi is not carried as far as in the case of the efferent ducts. At the cephalic and caudal ends of the vesicles, the epithelium loses its irregular character and assumes a strict columnar condition, where it graduates at one end into the epithelium of the accessory glands and at the other into that of the ejaculatory duct. The vesicles are chambers for the retention of the semen and are not centers of secretion. This latter process is localized in the vasa deferentia.

Nussbaum (1882) originally considered the vesicles, as well as the accessory glands, ejaculatory duct and penis, as derivatives of the ectoderm. Others, who also have made extensive studies of the reproductive system, believe the vesicles to be of mesodermal origin. At any rate, they are so similar to the vasa deferentia, and sufficiently unlike the other organs, to be called distentions of the former, and therefore of a mesodermal nature.

Kochevnikow (1891) found in the seminal vesicles of the honey bee, two layers of muscle, an inner circular one and an outer longitudinal. He could find none on the vasa deferentia. In the Saturniidæ, there is one layer of muscle, this is circular, and is a continuation of that found on the vas deferens (Fig. 17). 


\section{THE ACCESSORY GLANDS.}

In the accessory glands, the cells do not become conspicuously glandular, as might be expected from the terminology of these organs.

The cells remain columnar in character and do not form pseudonidi. They do not become vacuolate, in the same sense that the cells of the vas deferens become vacuolate. The cytoplasm presents a very spongy appearance, that is present in very young cells of the glands. At first this condition might easily be taken for a general vacuolization. Comparisons with other types of cells show that it is quite different, however. Many authors believe that there is a secretion of these organs, and that the secretion causes the formation of spermatophores. This may be true. Secretion is not as evident as in the cells of the glandular part of the vas deferens, and proceeds in a different manner.

The accessory glands differ from the organs previously discussed, in the possession of a single longitudinal layer of muscle. This in early stages of the development of the reproductive system may be continuous with the muscle of the upper end of the ejaculatory duct. This has not been definitely determined.

Koschevnikow (1891) found three layers of muscle in the glands of Apis; an inner longitudinal layer which may not extend the entire length of the tubes, a central circular and an outer longitudinal.

In some insects the accessory glands may actually be ectodermal in origin. Many authors do not believe so, however. If they were ectodermal, there would be a tendency toward the formation of an intima, which, as far as has been determined, does not exist in them.

\section{THE EJACULATORY DUCT.}

As stated previously, the ejaculatory duct consists of two parts, at least it is so considered by several authors, prominent among whom is Schroeder. The upper part is divided into two tubes, the ductus ejaculatorius duplex (of Schroeder), which are short and connect at their cephalic end with the seminal vesicles. These tubes are probably simply caudal prolonga- 
tions of the seminal vesicles. Their epithelium is somewhat similar to that of the vesicles and their musculature is the same.

Passing caudad to the union of this so-called ductus ejaculatorius duplex, we find we have a change in the musculature, which now takes on a longitudinal course. (Fig. 19). For quite a distance the epithelium retains its uniform columnar appearance. The longitudinal muscle is characteristic of the ductus ejaculatorius simplex, which is the caudal portion leading to the base of the penis. Undoubtedly this duct is ectodermal in origin. It is an invagination of the hypodermis and bears, for more than one-fifth of its length, a prominent intima. Above the caudal fifth the chitinous lining becomes thin and indistinct and is wanting at the juncture of the ductus ejaculatorius simplex and "duplex."

The longitudinal muscle, characteristic of the upper end of the single tube, has added to it, a prominent layer of circular muscle about half way along the duct (Fig. 20). The circular muscle appears outside of the longitudinal. Toward the caudal extremity the musculature becomes very uneven and very prominent, till about the so-called "bulbus ejaculatorius," it is very heavy, and interwoven. A third, outer longitudinal layer is added (Fig. 21). Koschevnikow could not find muscle in the ejaculatory duct of Apis mellifica. This seems very strange, in view of the function of this organ.

The epithelium of the ejaculatory duct goes through a metamorphosis comparable with that of the vasa deferentia, i. e., it forms pseudonidi, but these are covered over with the intima. In the so-called "ejaculatory bulb," the epithelium is actually folded, assuming the appearance of the epithelium of the proventriculus.

What by some authors is called the ejaculatory bulb is in reality a continuation of the simplex duct, with abundant muscle, with no enlargement, but a reduction of its lumen. Its function is to force the seminal fluid through the chitinous penis.

\section{CONCLUSION.}

(1) The Saturniid testis belongs to Chlodkovsky's second (larval) type, consisting of four testicular tubes combined in a common capsule.

(2) The greatest changes take place during the pupal stage. 
(3) The inner coat, of the testis and not the outer one, is fatty in nature.

(4) Verson's cell is a modified follicular epithelium, giving rise to the spermatocyst capsules.

(5) The cells of the vas deferens are the source of the seminal fluid, the accessory glands and seminal vesicles are storehouses.

(6) The accessory glands have a longitudinal layer of muscle; the seminal vesicles a circular layer, the upper end of the ejaculatory duct has longitudinal muscles, the lower portion has added a circular and an outer longitudinal layer as well.

( 7 ) There is a definite and complicated innervation of the internal genital organs.

\section{BIBLIOGRAPHY.}

1. Berlese, A. 1909. Gli Insetti. Milan.

2. Bessels, E. 1857. Studien über die Entwicklung der Sexualdrüsen bei den Lepidopteren. Zeit. f. Wiss. Zool. Vol. XVII.

3. Blatter, P. 1892. Sur l'histologie des organes annexes de l'appareil male chez la Periplaneta orientalis. Comptes Rendus CXV. 1332-1334.

4. Blatter, P. 1897. Etude sur la structure histologique des glandes annexes de l'appareil male de 1'hydrophile. Arch. Anat. Micro. Vol. I. 384-910.

5. Bordas, L. 1900. Recherches sur les organes reproducteurs males des Coleopteres. Ann. Sc. Nat. Zool. Vol. 2. 283-448.

6. Cholodkovsky, N. N. 1880. Über die Hoden der Schmetterlinge. Zool. Anz. Vol. III. 115-117, 214-215.

7. Cholodkovsky, N. N. 1884. Úber die Hoden der Lepidopteren. Zool. Anz. Vol. VII. 564-568.

8. Cholodkovsky, N. N. 1892. Zur Kenntnis der Männerlichen Geschlechtsorgane der Dipteren. Zool. Anz. XV. 178-180.

9. Cholodkovsky, N. N. 1905. Über den Bau des Dipterenhodens. Zeit. f, wiss. Zool. Vol. XXXII. 389-410.

10. Cholodkovsky, N. N. 1913. Zur Kenntniss der Trichopteren und Lepidopteren Hodens. Zool. Anz. Vol. XLII.

11. Demokidoff, K. 1902. Zur Kenntniss des Baues des Insectenhodens. Zool. Anz. Vol. XXV. 575-578.

12. Gruenberg, K. 1903. Untersuchung über die Keim und Nahrzellen in der Hoden und Ovarien der Lepidopteren. Zeit. f. wiss. Zool. Vol. LXXIV. 327-395.

13. Hasse, E. 1887. Die Vorfahren der Insecten. Abhand. Gesell. Isis. Dresden. Vol. XI.

14. Herold, M. J. D. 1815. Entwicklungsgeschichte der Schmetterlinge, anatomisch u. physiologisch bearbeitet. Cassel. w. Marburg.

15. Henneguy, F. M. 1904. Les Insectes. Paris.

16. Kellogg, V. L. 1907. Sex differentiation in larval insects. Biol. Bull. Vol. XXII.

17. Koschevnikow, G. 1891. Zur Anztomie der männlichen Geschlechtsorgane der Honigbiene. Zool. Anz. Vol. XIV.

18. Landois, H. 1863. Über die Verbindung der Hoden mit dem Rückengefass bei der Insekten. Zeit. f. Wiss. Zool. Vol. XIII. 316-18. 
19. Lecaillon, A. 1902. Sur le testicule d'Anurida maritima. Bull. Soc. Ent. France. 64-67.

20. Lecaillon, A. 1902. Sur la disposition, la structure et le fonctionnement de l'appareil reproducteur mâle des Collemboles. Bull. Soc. Philom. Vol. IV. 99-103.

21. Lowne, B. T. 1895. Anatomy of the Blow Fly. Vol. II. p. 660. London.

22. Malpighi, M. 1669. Dissertatio epistolica de Bombyce, Societati regiae Londini ad scientiam naturalem promovendam institutae dicata. London.

23. Meves, F. 1907. U̇ber Centralkörper in Männerlichen Geschlechtszellen von Schmetterlingen. Anat. Anz. Vol. XIV.

24. Nusbaum, J. 1882. Zur Entwicklungsgeschichte der Ausführungsgange der Sexualdrüsen bei der Insecten. Zool. Anz. Vol. V. 637-643.

25. Packard, A. S. 1898. Textbook of Entomology. New York.

26. Peterson, W. 1900. Beiträge zur Morphologie der Lepidopteren. Mem. Acad. St. Petersbourg. Vol. IX.

27. Peterson, W. 1904. Die Morphologie der Generations-organs der Schmetterlinge und ihre Bedeutung für die Artbilding. Mem. Acad. St. Petersbourg. Vol. XVI.

28. Peterson, A. 1912. Anatomy of the Tomato Worm Larva Protoprace carolina. Ann. Ent. Soc. Amer. Vol. V. 246-49.

29. Riley, W. A. 1915. Laboratory Outlines in Entomological Histology.

30. Saint-George, LaValette. 1897. Zur Samen und Eibildung beim Seidenspinnen (B. mori). Arch. Mikr. Anat. Vol. I.

31. Schneider, A. 1883. Úber die Entwicklung der Geschlechtsorgane der Insekten. Zool. Beitrage v. A. Schneider. Vol. I.

32. Schroeder, Chr. 1912. Handbuch der Entomologie. Jena.

33. Severin, H. H. P. and H. C. M. 1908. Internal organs of reproduction of the male saw-fly. Cimbex americana Leach. Ann. Ent. Soc. Amer. Vol. I. 196-206.

34. DeSintey, R. 1900. Homologation du testicule chez les Phasmes. Bull. Soc. Ento. de France. Vol.

35. DeSintey, R. 1901. Recherches sur la biologie des Phasmes. La Cellule, 1901.

36. Spichardt, C. 1886. Beitrag zur Entwickelung der männlichen genitalen und ihrer Ausführgange bei Lepidopteren. Ver. d. Nat. Vereins zu Bonn. 43 Jahrg.

37. Stitz, H. 1903. Zum Genitalapparat der Lepidopteren. Zool. Anz. Vol. XXVII

38. Tichomiroff, A. 1880. Bau der Sexualdrüsen und Entwicklung der Sexualproducte bei Bombyx mori. Zool. Anz. Vol. III.

39. Tichomiroff, A. 1898. Zur Anatomie des Insectenhodens. Zool. Anz. Vol. XXI.

40. Toyama, N. K. 1894. On the spermatogenesis of the silk worm. Bull. Coll. Agri. Imp. Univ. Japan. Vol. II.

41. Verson, E. 1889. Zur Spermatogenesis. Zool. Anz. Vol. XII.

42. Verson, E. 1889. La Spermatogenesi nel Bombyx mori. Padova.

43. Verson, E. F. and Bisson, E. 1895. Development postembryonnaire des organes sexual accessoires chez le male du Bombyx mori. Arch. Ital. de Biol. Vol. XXIV.

44. Verson, E. 1899. Sullufficio della cellula gigante nei follicoli testicolari degli insetti. Atti. Ist. Venet. Vol. LVII.

45. Verson, E. 1904. Zur Entwicklungsgeschichte der mannlichen Geschlectsanhänge bei Insecten. Zool. Anz. Vol. XXVII.

46. Verson, E. 1911. Über die Versonsche Zelle der Autoren in den Hodenfächern der Lepidopteren. Zool. Anz. Vol. XXXVIII.

47. Zick, Karl. 1911. Beiträge zur Kenntniss postembryonalen Entwicklungsgeschichte der Genitalorgane bei Lepidopteren. Zeit. f. wiss. Zool. Vol. XCVIII. 


\section{EXPLANATION OF PLATES}

Plate X.

Fig. 1. A, B, C, D. Chlodkovsky's four types of Lepidopterous testes. A, Hepialus; B, Saturnia; C, Lycaena; D, Pieris. All diagramatic. E, adult genital system in Samia cecropia, semi-diagramatic. $\times 8$.

Fig. 2. Sagittal section of testis, showing chambers, hilum, and two coats. Diagramatic.

Fig. 3. Detail of hilum of testis. Note the continuity of the basement membrane of the chamber with that of the epithelium of the vas deferens. Camera lucida drawing.

\section{Plate XI.}

Fig. 4. The relation of the nervous and reproductive systems in an early pupal stage of Philosamia cynthia.

Fig. 5. Detail of coats of testis of Callosamia promethia.

Fig. 6. Detail of coats of testis of Philosamia cynthia.

Fig. 7. Detail of apical region of a chamber in the testis of Pieris rapa, showing Verson's cell giving rise to spermatocyst capsules. The black particles in the cytoplasm of the apical cell are portions of the parent nucleus, (probably formed by amitosis) migrating to the fibrous prolongations to become the nuclei of the spermatocyst capsule.

Fig. 8. Adult (sperm stage) spermatocyst.

\section{PLATE XII.}

Figs. 9-15. Growth of the epithelium of vas deferens from larval (or early pupal) stage (9) to the late pupa, (13) when the cytoplasm contains secretion droplets, to the adult stage (15), when the secretion dróplets disappear and the tips of the cells vacuolize.

Fig. 16. Trans-section of vas deferens, showing general contour of epithelium.

Fig. 17. Epithelium of upper end of seminal vesicle.

Fig. 18. Epithelium of accessory glands.

Fig. 19. A, Trans-section of ejaculatory duct, near its union with the "ductus ejaculatorius duplex." B, Epithelium of same."

Fig. 20. Trans-section of ejaculatory duct midway along its length. Note the addition of circular muscle.

Fig. 21. Trans-section of ejaculatory duct near ejaculatory "bulb." Note the addition of muscles and the presence of an intima.

Each scale line is equivalent to 100 micra.

\section{ABBREVIATIONS.}

Ac.-Apical cell (Verson's cell) Follicular epithelium.

Ag.-Accessory glands.

Be.-Ejaculatory "'bulb."

Bm.-Basement membrane.

Cc.-Capsular coat.

Cm.-Circular muscles.

Cp.-Caudal plexus.

Ded.- "Duetus ejaculatorius duplex."

Des.-Ductus ejaculatorious simplex.

Epi.--Epithelium (of genital ducts).

Fd.-Fat droplets.

I.-Intima.

Lm.-Longitudinal muscles.

Lvd.-Lumen of vas deferens.

P.-Penis.

Pg.-Pigment granules.

Sd.-Secretion droplets.

Sp.-Spiracle.
Spc.-Spermatocyst capsule (follicular epithelium).

Spg.-Spermatogonia.

Spn.-Nucleus of spermatocyst capsule.

Spv.-Vestigial spiracle.

Sv.-Seminal vesicles.

T.-Testis.

Tm.-Tracheal membrane.

Tr.-Tracheæ.

Ttc.-Testicular tube coat.

Vd.-Vas deferens.

Vp.-Vesicular plexus.

For Fig.. 4.

$7,8,9,10$-Abdominal nerves.

A-Anterior.

$\mathrm{P}$-Posterior.

S-Sympathetic. 


\section{$2 \mathrm{BHL}$ Biodiversity Heritage Library}

Ruckes, Herbert. 1919. "Notes on the Male Genital System in Certain Lepidoptera." Annals of the Entomological Society of America 12, 192-209. https://doi.org/10.1093/aesa/12.3.192.

View This Item Online: $\underline{\text { https://www.biodiversitylibrary.org/item/43720 }}$

DOI: https://doi.org/10.1093/aesa/12.3.192

Permalink: https://www.biodiversitylibrary.org/partpdf/193559

\section{Holding Institution}

Smithsonian Libraries

\section{Sponsored by}

Smithsonian

\section{Copyright \& Reuse}

Copyright Status: NOT_IN_COPYRIGHT

This document was created from content at the Biodiversity Heritage Library, the world's largest open access digital library for biodiversity literature and archives. Visit BHL at https://www.biodiversitylibrary.org. 